\title{
Industrial By-Products: Stress Factors or Nutrients?
}

\author{
Brigitta Tóth, Géza László Nagy, Szilvia Veres, László Nagy, and László Lévai \\ University of Debrecen, Department of Agricultural Botany and Crop Physiology, Debrecen, Hungary \\ Email: \{btoth, szveres, levai\}@ agr.unideb.hu, nagy.laszlo.agricultura@gmail.com,
}

\begin{abstract}
The reduction of fertilizer's portion has become essential in the crop production by now. The aim of our work was to examine four industrial by-products (sewage sludge, flue-gas, extruded poppy-heads) in order to determine whether the examined by-products can be potentially used for the nutrition of plants. The dry matter accumulation, relative chlorophyll contents of the plants, as well as the absolute quantities of photosynthetic pigments, the concentrations of various elements in the shoots and roots were measured. We have come to the conclusion that all of the examined by-products can be used in the nutrition supply of plants, but it is essential to determine the concentrations of application accurately for field use.
\end{abstract}

Index Terms - crop production, environmental protection, plant nutrition, poppy-heads, sewage sludge

\section{INTRODUCTION}

The growth of agricultural chemical use is an integral part of the technological revolution in agriculture that has generated major changes in production techniques, shifts in input use, and growth in output and productivity. The mechanization revolution of the 1930s and 1940s has been augmented since 1945 by a biological revolution in terms of fertilizer [1]. That biological revolution continues. A consequence of these changes is that farmers use more fertilizer, but less work.

An adequate supply of nutrients is essential to crop growth. Ideally, soil nutrients should be available in the proper amounts at the time the plant can use them. Relatively heavy use of nitrogen and some other fertilizers, however, can lead to soil acidification, other changes in soil properties, and offsite environmental problems. Fertilizers are sometimes over applied. Crops are much more likely to fully utilize nitrogen that is properly timed. Unused nitrogen can be immobilized, denitrified, washed into surface water, or leached into groundwater [2].

The agricultural crops reduce the green-house effect because they bind $\mathrm{CO}_{2}$ which contributes to the causing of green-house effect by about $50 \%$. The production of fertilizers is not only expensive but it is a procedure which needs enormous energy. The reduction of fertilizer's portion has become essential in the crop production by now. One of the reasons for that is during other industrial activities such as by-products are produced in high quality in which the necessary nutrients for plants can be found in a big amount. These nutrients have high organic content. This is a fundamental essential condition for the microorganisms appearing in the soil without which the sustainable crop production cannot be achieved.

Besides the high fertilizer prices the use of produced wastes is economically reasonable. Finally, the other reason for the reduction of fertilizer use is that the inappropriate use of the fertilizers may cause environmental pollution.

During our work, we would like to find solution with the use of wastes and by-products. During the different industrial and production procedures and probably during everyday use some by- products and wastes are generated which have high micro- and macro element content and they do not endanger the environment. They should not be handled as wastes but rather as nutrient amendments.

\section{MATERIALS AND METHODS}

Maize (Zea mays L cvs. PR37NO1) seeds were sterilized with $18 \%$ hydrogen peroxide, and washed in distilled water, and placed in $10 \mathrm{mM} \mathrm{CaSO} 4$ for 4 hours. Seeds were germinated on moistened filter paper at $250 \mathrm{C}$. The seedlings were transferred to continuously aerated nutrient solution of the following composition: $2.0 \mathrm{mM}$ $\mathrm{Ca}(\mathrm{NO} 3) 2,0.7 \mathrm{mM}$ K2SO4, $0.5 \mathrm{mM} \mathrm{MgSO} 4,0.1 \mathrm{mM}$ KH2PO4, $0.1 \mathrm{mM} \mathrm{KCl}, 1 \mu \mathrm{M} \mathrm{H} 3 \mathrm{BO} 3,1 \mu \mathrm{M} \mathrm{MnSO} 4,1$ $\mu \mathrm{M} \quad \mathrm{ZnSO} 4, \quad 0.25 \mu \mathrm{M} \quad \mathrm{CuSO} 4$, and $0.01 \mu \mathrm{M}$ (NH4)6Mo7O24. Iron was added as Fe (III)-EDTA at a concentration of $100 \mu \mathrm{M}$. Extruded poppy heads, flue gas and sewage sludge were added at rate of $2 \mathrm{~g} \mathrm{~L}-1$ to the nutrient solution.

Seedlings were grown under controlled environmental conditions (light/dark regime $10 / 14 \mathrm{~h}$ at $24 / 20 \mathrm{oC}$, relative humidity of $65-70 \%$ and a photon flux density of 300 $\mu \mathrm{mol} \mathrm{m}-2 \mathrm{~s}-1)$ in controlled environmental room. The volume of experiment pots were $1.7 \mathrm{~L}$, one pot contains 4 plants.

The elements contents were checked with the use of OPTIMA 3300DV ICP-OA Spectrophotometer.

The contents of chlorophyll $\mathrm{a}, \mathrm{b}$ and carotene were measured by spectrophotometer (Meterek SP 80). The data obtained after the spectrophotometrycal formula proposed by Moran and Porath [3]. 
The dry weight of shoots and roots were measured with thermal gravimetric analysis. Plant samples were drying at $85 \mathrm{C}^{\circ}$ for $48 \mathrm{~h}$.

\section{RESULTS}

The effect of any nutrients can be considered directly, when the plants take it up, and the element gets into the living cell. Then the elements will be transferred to the different part of plant. The tolerant plants exclude the harmful elements from their metabolism, through the excretion of the elements to the vacuole. The sensitive plants are not able to transfer these elements from the roots, therefore these accumulate, causing the changing of membrane functions, and also effect on osmotic potential. The concentrations of examined elements in the shoots and roots of corn can be seen in Table I treated by different by-products.

TABLE I. ELEMENT CONTENT IN THE SHOOTS AND RoOTS OF MAIZE $\left(\mathrm{MG} \mathrm{KG}^{-1}\right)$

\begin{tabular}{|c|c|c|c|c|}
\hline \multicolumn{5}{|c|}{ Element content in the shoots of maize } \\
\hline Treatments & $\mathrm{Ca}$ & $\mathrm{K}$ & $\mathrm{Mg}$ & $\mathrm{P}$ \\
\hline Control & $8006 \pm 147$ & $\begin{array}{c}80074 \pm \\
593\end{array}$ & $2003 \pm 132$ & $13987 \pm 38$ \\
\hline Flue-gas & $7400 \pm 730$ & $\begin{array}{c}80146 \pm \\
751\end{array}$ & $1996 \pm 477$ & $\begin{array}{c}12012 \pm \\
2790\end{array}$ \\
\hline $\begin{array}{l}\text { Extr.poppy- } \\
\text { heads }\end{array}$ & $4656 \pm 329$ & $\begin{array}{c}37820 \pm \\
1450\end{array}$ & $1218 \pm 340$ & $7500 \pm 237$ \\
\hline $\begin{array}{c}\text { Sewage } \\
\text { sludge }\end{array}$ & $9884 \pm 383$ & $\begin{array}{c}101446 \pm \\
4621 \\
\end{array}$ & $2606 \pm 60$ & $\begin{array}{c}15770 \pm \\
651 \\
\end{array}$ \\
\hline \multicolumn{5}{|c|}{ Element content in the roots of maize } \\
\hline Treatments & $\mathrm{Ca}$ & $\mathrm{K}$ & $\mathrm{Mg}$ & $\mathrm{P}$ \\
\hline Control & $7773 \pm 43$ & $\begin{array}{c}51065 \pm \\
1898\end{array}$ & $4714 \pm 86$ & $5412 \pm 85$ \\
\hline Flue-gas & $\begin{array}{c}83937 \pm \\
243\end{array}$ & $9471 \pm 219$ & $1108 \pm 35$ & $2426 \pm 46$ \\
\hline $\begin{array}{l}\text { Extr.poppy- } \\
\text { heads }\end{array}$ & $8142 \pm 195$ & $\begin{array}{c}48986 \pm \\
5279\end{array}$ & $4404 \pm 226$ & $6453 \pm 65$ \\
\hline $\begin{array}{l}\text { Sewage } \\
\text { sludge }\end{array}$ & $5311 \pm 252$ & $\begin{array}{c}41211 \pm \\
502\end{array}$ & $2947 \pm 314$ & $4020 \pm 99$ \\
\hline
\end{tabular}

The concentrations of examined elements decreased in the shoots of maize at flue-gas treatment, except the K, where slight increase was measured. The highest decrease was in case of P. In general, the concentration of all examined element decrease in the shoots due to the treatments, while significant increase of $\mathrm{Ca}$ was observed in the roots. The increase of $\mathrm{Ca}$ concentration raises several questions. The optimal $\mathrm{Ca}$ concentration in the citosol is $1 \mathrm{mM}$ [4]. To obtain this relatively low $\mathrm{Ca}$ concentration, the cells excrete $\mathrm{Ca}$ in energy demand processes. The total $\mathrm{Ca}$ concentration includes the apoplasmatic and symplasmatic $\mathrm{Ca}$ concentration, we can suppose the increase of ca concentration inside the cells. The root cells were not able to release these higher amounts of $\mathrm{Ca}$, because there was not enough energy (ATP) to cover the energy demand of process.

The data of Table I gives interesting details according to the transport processes. The root to shoot transport of $\mathrm{K}$ was extremely intensive at the control, and at the treatment by flue gas and sewage sludge. The observation was the same in case of $\mathrm{P}$. The high concentration of $\mathrm{P}$ and $\mathrm{K}$ in the shoots let us make a conclusion of a more intensive carbohydrate metabolism.

The concentration of all examined elements decreased in the shoot of corn when extruded poppy head treatment was applied. This decrease happened in spite of the fact that the concentrations of measured elements were extremely high in the roots. This observation draws our attention to the importance of transport processes.

The optimal nutrient supply is usually achieved by the application of fertilizers in crop production [5]. The investigated elements can influence the growth when they accumulated in larger or smaller quantities in plants, so we measured the dry matter accumulation of shoots and roots, length of shoots and roots of maize. The dry weight of maize can be seen in Table II.

TABLE II. EFFECTS OF FLUE GAS, EXTRUdED POPPY-HEADS AND SEWAGE SLudGE ON THE DRY WeIGHT OF MAIZE (G PlANT-1) N=9 \pm S.E. SIGNIFICANT DIFFERENCES COMPARED TO THE CONTROL: ${ }^{*} \mathrm{P}<0.05$; $* * * \mathrm{P}<0.001$

\begin{tabular}{|c|c|c|}
\hline \multicolumn{3}{|c|}{ Dry weigth of shoots and roots } \\
\hline Treatments & Shoots & Roots \\
\hline \hline Control & $0.199 \pm 0.02$ & $0.064 \pm 0.01$ \\
\hline Flue-gas & $0.128 \pm 0.02^{\star \star *}$ & $0.023 \pm 0.00^{\star \star *}$ \\
\hline Extr.poppy-heads & $0.180 \pm 0.04$ & $0.052 \pm 0.01$ \\
\hline Sewage sludge & $0.262 \pm 0.06^{\star}$ & $0.067 \pm 0.01$ \\
\hline
\end{tabular}

The dry matter of shoots and roots of maize significantly decreased at the flue gas treatment. The formation of lateral roots was cramped which can be explained with the high $\mathrm{pH}$ of flue gas and with the insufficient nutrient supply.

The dry matter of shoot and root of maize decreased at the extruded poppy-heads treatment. The decrease is not significant.

The dry matter of shoots and roots of maize is increased at the sewage sludge treatment. The increase was significant in the shoot.

TABLE III. THE RELATIVE CHLOROPHYLl CONTENT (SPAD-UNIT) IN SECOND AND THIRD LEAVES OF MAIZE ON THE $6^{\mathrm{TH}}, 9^{\mathrm{TH}}$ AND $11^{\mathrm{ST}}$ DAYS OF THE EXPERIMENT. N=60 \pm S.E. SIGNIFICANT DIFFERENCES COMPARED TO THE CONTROL: ${ }^{*} \mathrm{P}<0.05$; $*^{*} * *_{\mathrm{P}}<0.001$

\begin{tabular}{|c|c|c|c|}
\hline \multicolumn{4}{|c|}{ Relative chlorophyll content in the $2^{\text {nd }}$ leaves of maize } \\
\hline Treatments & 6th day & 9th day & 11th day \\
\hline Control & $36.77 \pm 3.35$ & $37.27 \pm 3.92$ & $38.38 \pm 2.31$ \\
\hline Flue-gas & $34.70 \pm 3.82$ & $33.34 \pm 4.34^{*}$ & $30.36 \pm 2.73^{* * *}$ \\
\hline $\begin{array}{c}\text { Extr.poppy- } \\
\text { heads }\end{array}$ & $39.35 \pm 3.56$ & $42.30 \pm 4.61^{\star * *}$ & $39.49 \pm 2.67$ \\
\hline Sewage sludge & $38.69 \pm 2.11$ & $43.67 \pm 3.51^{* * *}$ & $43.79 \pm 1.64^{* * *}$ \\
\hline \multicolumn{4}{|c|}{ Relative chlorophyll content in the $3^{\text {rd }}$ leaves of maize } \\
\hline Treatments & 6th day & 9th day & 11th day \\
\hline Control & $29.74 \pm 3.46$ & $28.61 \pm 4.99$ & $24.94 \pm 2.20$ \\
\hline Flue-gas & $25.40 \pm 2.83^{*}$ & $26.01 \pm 3.36$ & $25.99 \pm 2.89$ \\
\hline $\begin{array}{c}\text { Extr.poppy- } \\
\text { heads }\end{array}$ & $28.73 \pm 2.66$ & $27.94 \pm 6.09$ & $31.48 \pm 4.21^{\text {***}}$ \\
\hline Sewage sludge & $32.12 \pm 4.32$ & $37.17 \pm 2.34^{\star \star \star}$ & $37.58 \pm 2.82^{\star \star *}$ \\
\hline
\end{tabular}


Low chlorophyll contents affect photosynthetic activities. The decreasing dry matter accumulation can be explained by the lower level of the chlorophyll contents. With respect to this later suggestion, we measured the relative chlorophyll and chlorophyll $a-, b$ contents in the $2^{\text {nd }}$ leaf of maize. Total chlorophyll concentration is a unifying parameter for indicating the effect of specific interventions. The results are shown in Table III and Table IV.

The SPAD-unit is increased on all measuring days in the second leaves of maize at the extruded poppy-heads. The increase was significant on the $11^{\text {th }}$ day in the third leaves. I suppose that the synthesis of photosynthetic pigments is a slower process than the growth of leaf. Thus, the total pigment concentration has not finished at the total leaf size developing. The synthesis of photosynthetic pigments needs energy and materials. So, I suppose that one of the highest quantities of the produced energy during the leaf-differentiation turns to the structure formation and after the finishing the synthesis of photosynthetic pigments.

The SPAD-unit increased in the second and third leave of maize on all measuring days at the sewage sludge treatment compared to the control. The increase was significant on the $9^{\text {th }}$ and on the $11^{\text {th }}$ days.

Since taking relative chlorophyll values gives only relative readings the volumes of photosynthetic pigments (chlorophyll- $a$, chlorophyll- $b$, carotenoids) were also taken (Table IV).

TABLE IV. CHLOROPHYLL-A AND B CAROTENOIDS CONTENT (MG G-1) IN THE $2^{\text {ND }}$ AND $3^{\text {RD }}$ LEAVES OF MAIZE UNDER THE EFFECTS OF FLUE Gas, ExTRuded PopPy-HEADS AND SEWAGE SLUdGE TREATMENTS $\mathrm{N}=9 \pm$ S.E. SigNIFICANT DIFFERENCES COMPARED TO THE CONTROL: $*_{\mathrm{P}}<0.05 ; *^{*} *_{\mathrm{P}}<0.001$.

\begin{tabular}{|c|c|c|c|}
\hline \multicolumn{4}{|c|}{ Chlorophyll content in the $2^{\text {nd }}$ leaves of maize } \\
\hline Treatments & Chlorophyll-a & Chlorophyll-b & Carotenoids \\
\hline Control & $12.44 \pm 0.61$ & $3.51 \pm 0.41$ & $8.53 \pm 0.89$ \\
\hline Flue-gas & $11.53 \pm 0.60$ & $2.92 \pm 0.57$ & $7.60 \pm 0.02$ \\
\hline Extr.poppy-heads & $11.22 \pm 0.52$ & $2.97 \pm 0.59$ & $6.95 \pm 0.76$ \\
\hline Sewage sludge & $13.63 \pm 1.75$ & $3.54 \pm 0.74$ & $8.16 \pm 0.75$ \\
\hline \multicolumn{4}{|c|}{ Chlorophyll content in the $3^{\text {rd }}$ leaves of maize } \\
\hline Treatments & Chlorophyll-a & Chlorophyll-b & Carotenoids \\
\hline Control & $8.79 \pm 0.38$ & $3.48 \pm 0.99$ & $5.92 \pm 0.69$ \\
\hline Flue-gas & $9.95 \pm 0.22^{*}$ & $2.67 \pm 0.25$ & $6.92 \pm 0.31$ \\
\hline Extr.poppy-heads & $7.55 \pm 0.43^{*}$ & $1.79 \pm 0.34^{*}$ & $5.24 \pm 0.14$ \\
\hline Sewage sludge & $14.04 \pm 0.55^{\star}$ & $4.15 \pm 0.69$ & $9.12 \pm 0.71^{*}$ \\
\hline
\end{tabular}

Chlorophyll content readings are similar to SPADvalue readings of flue gas treatments. On the basis of the detailed measurement it can be stated that the treatment brings about changes in chlorophyll- $b$ concentrations, primarily. Chlorophyll- $a$ contents decreased in the older second leaves while they increased in the subsequent mature ones under the influence of the treatment.

The increases in SPAD-values under the influence of the compost treatment are supported by the values showing absolute concentrations of photosynthetic pigments.

The absolute volumes of photosynthetic pigments decreased in the case of leaves of any age when extruded poppy-heads treatment was applied. In the third, the younger leaf, this decrease is significant, which supports the earlier explanation, namely that the time curves of leaf growth and syntheses of photosynthetic pigments do not coincide. The decrease in the pigment levels in older leaves in relation to the control may be a cause of the more moderate organic matter accumulation in the plants treated.

\section{CONCLUSIONS}

All of the by-products involved into the experiments are generated in huge volumes; therefore, they can be suitable for solving nutrient deficiency problems in large agricultural fields. It has been confirmed by the experiments focusing on the nutritional elements of the by-products that all the by-products contain several essential elements in large quantities. My examinations concentrated on the elements that occur in all the byproducts. From among them, we have selected the four elements serving as the basis of comparison: $\mathrm{Ca}, \mathrm{K}, \mathrm{Mg}$ and $\mathrm{P}$.

The use of these by-products in agriculture offers us the possibility to moderate the quantities of expensive mineral fertilizers used in agriculture.

The criteria of their application include that they should not exercise any toxic effect on plants or pollute the environment, but can be used in replacement of the expensively manufactured chemicals

In the light of the experiments, we have come to the conclusion that all of the examined by-products can be used in the nutrition supply of plants, but it is essential to determine the concentrations of application accurately for field use. This statement is particularly true for flue-gas powder.

In summary of the results, we found that the byproducts that were subjected in our experiments may be used in full or partial replacement of the costly chemicals as the case may be, though as the composition of the byproducts, e.g. sewage sludge, may change, it is necessary to continuously monitor the by-products designed for the above use.

\section{REFERENCES}

[1] G. A. Carlson and E. N. Castle, "Economics of pest control: Pest control strategies for the future," Washington: National Academy of Sciences, 1972.

[2] W. Huang and R. Lantin, "A comparison of farmer's compliance costs to reduce excess nitrogen fertilizer use under alternative policy options," Rev Agric Econ, vol. 15, pp. 51-62, 1993.

[3] R. Moran and D. Porath, "Chlorophyll determination in intact tissues using N, N-Dimethyl-formamide,” Plant Physiol., vol. 65, pp. 478-479, 1980.

[4] P. Marschner, Marschner's Mineral Nutrition of Higher Plants, P. Marschner Ed., Academic Press, USA, 2012.

[5] T. L. Roberts, "Improving nutrient use efficiency," Turk. J. Agric. For., vol. 32, pp. 1777-182, 2008. 
Brigitta Tóth was born on 23, June, 1984 in Miskolc, Hungary. She graduated from Kálmán Kerpely Doctoral (PhD) School of Crop Sciences, Horticultural and Regional Sciences, University of Debrecen, Debrecen, Hungary in 2012. She also had Plant physiology examination of industrial by-products.

She had got Hungarian State Eötvös PostDoc Scholarship to Hohenheim University for 4 months.

She is an assistant lecturer at the University of Debrecen. Dr. Tóth has memberships at FESPB and IPS 